\title{
INCOME TAX WITHHOLDING FROM INDIVIDUALS: A COMPARATIVE ANALYSIS OF THE LEGISLATION OF THE REPUBLIC OF AZERBAIJAN AND TURKEY
}

\author{
GASIMZADE Ramiz - Doctoral Candidate of National Aviation of Azerbaijan, \\ PhD in law
}

DOI:10.32782/LAW.2020.1.28

The article indicates that comparative law acts as an important form of development of international relations. Comparative law carries a high charge of legal culture, actively contributes to the development of legal thinking, provides the necessary knowledge for the lawyer.

Keywords: Azerbaijan, law, comparative, country, tax.

Comparative jurisprudence, called comparativism in modern jurisprudence, deals with the comparison of the general properties of different legal systems and the specific features of their manifestations. Comparativism involves comparing legal entities that exist in the past or present. Therefore, any legal norm or legal institution can be taken as an object for comparative research. Guliyev A.I. rightly points out that "the comparative-legal approach includes such methods and means by which the legal systems of different countries are compared in order to determine the general features and specific features of modern manifestations. Such a comparison involves the study of the overlapping characteristics of laws and legislation that currently exist in different legal systems (synchronous comparison).

For comparison legislative acts (microcomparison), more complex components of their associations (institutional, sectoral and intersectoral comparison), as well as the legal system as a whole (macrocomparison) can be selected" $[4$, p. 5].

Professor Jafarli N.H. rightly notes that "comparative law is of great importance for legal science, especially for national law. It teaches how to solve certain legal problems in different countries, expands the scope of legal research, the pros and cons of the experience are evaluated. In modern times, general conclusions drawn without reference to the information provided by comparative law cannot be generalized or many-sided.

On the other hand, a number of legal concepts that have taken root in jurisprudence need to be updated with reference to the legal experience of foreign countries and the legal thinking established in the world" [2, p. 30].

The French scholar Mansel rightly points out that "a lawyer's study of the legal experience of foreign countries helps him to better understand the law of his own country, provide him with ideas and arguments that could not be obtained even with a perfect knowledge of the law of his country" [5, p. 38].

For this reason, the study of the legislation of foreign countries, as well as the study of Turkish legislation on the withholding of personal income tax, is a topical issue both scientifically and practically.

Thus, in the study of personal income tax collection, it is especially important to conduct comparative research, study the legislation of foreign countries, as well as the legislation of Turkey and to identify their advantages and disadvantages. These are:

1) The study of the legal norms related to the withholding of income tax from individuals in the tax legislation of Turkey helps to deepen the knowledge on the issue under study; 
2) create a basis for making the best legal decisions on improving the norms of the Tax Code of the Republic of Azerbaijan related to the collection of income tax from individuals and for further updating of the national legislation;

3) currently contributes to the solution of such an important problem as the convergence of norms of national legislation on the collection of income tax from individuals

Pursuant to Article 102.1.6 of the Tax Code of the Republic of Azerbaijan, adopted by the Law of the Republic of Azerbaijan dated July 11, 2000 and entered into force on January 1, 2001, the following income of physical persons shall not be subject to income tax: "If monthly income, gained in connection with a paid job at the main workplace (where the labor record is maintained) of a physical person is up to 2500 (two thousand and five hundred) manats, then the part in the amount of 200 (two hundred) manats, if annual income is up to 3000 (three thousand) manats, then in the amount of 2400 (two thousand four hundred) manats shall not be subject to income tax".

Taking into account the provisions of Article 101.1-1 of the Tax Code, income tax from individuals in the Republic of Azerbaijan from January 1, 2019 shall be taxed at following rates:

- Amount of tax up to 2500 manats at a rate of 14 percent;

- Over 2500 manats 350 manats $+25 \%$ of the amount exceeding 2500 manats;

- From 1 January 2019, income tax for employees working in private non-oil-gas industry would be $0 \%$ for the monthly income of up to $8000 \mathrm{AZN}$, and $14 \%$ of the monthly income amount exceeding 8000 AZN for 7 years (Tax Code, Article 101.1-1);

- The annual income from non-business activity shall be taxed at a rate of 14 per cent (Tax Code, Article 101.2);

- Taxable income of individuals engaged in business activities without establishing a legal entity shall be taxed at a rate of 20 percent (Tax Code, Article 101-3);

- From the subject of taxation established in respect of private notaries by the second paragraph of Article 96.1 of this Code, tax is withheld at a rate of 10 percent( Tax Code, Article 101-4).
Articles 96-99 of the Tax Code specify the range of objects subject to income tax for residents and non-residents. Thus, the object of taxation on the income of residents is the taxable income, which is the difference between the total income of residents for the tax year and the amount of income deducted by the Tax Code for the same period.

The payment (excluding expenses) for notarial acts carried out by private notary within one month, as well as for services provided in connection with a notarial acts shall be a subject to taxation.

Where there is a tax at the source of payment, the object of taxation is taxable income.

A non-resident taxpayer engaged in activity in the Republic of Azerbaijan through a permanent establishment should be a payer of income tax with regard to taxable income connected with the permanent establishment. Taxable income shall be a difference between gross income generated in a specific period from Azerbaijani sources with regard to the permanent establishment and the amount of expenses with respect to the generation of said income during that period.

A non-resident physical person receiving employment income or income from the transfer of property shall be a payer of income tax with regard to gross income for the calendar year from a source in the Republic of Azerbaijan, reduced by the amount that are attributable to the income for that period, stipulated by the Tax Code.

Income shall cover:

- income received as the result of employment;

- income from activity which is not connected with employment;

- all other kinds of income except for taxexempt income and gain arising from the revaluation of fixed assets (funds).

Any payments or benefits received by a physical person from employment shall be income received in the form of salaries and wages.

Income from activity that is not connected with employment shall consist of incomes from entrepreneurial and non-entrepreneurial activity:

Income tax from the incomes of physical persons, working under contracts in two or 
more places, shall be calculated separately from the amount paid by each employer, and paid to the state budget.

See the following examples:

Example 1. A physical person working at the Azerbaijan National Academy of Sciences earns 1000 manat. According to Article 102.1.6 of the Tax Code, since 200 manat is exempted from income tax,the income tax will be $880 \times 14$ per cent $=112$ manat.

Example 2. A physical person working for BHGE (Baker Hughes General Electric) in Baku receives a salary of 3,000 (three thousand) manat. According to the Resolution of the Cabinet of Ministers of the Republic of Azerbaijan No. 56 dated February 18, 2019, the State Oil Company of the Republic of Azerbaijan and its affiliates, as well as contractors and companies operating on production sharing, main pipeline and other similar agreements, regardless of the type, as it is fully related to the oil and gas industry, the income tax of a physical entity working for BHGE will be 350 manat +125 manat $=475$ manat, taking into account the provisions of Article 101.1-1 of the Tax Code.

Example 3. The physical person let his apartment in Baku to the citizen of Turkey for 7200 (seven thousand and two hundred) manats for 1 year. In this case, an annual income of the physical person gained in the amount of 7200 manat from rent is considered to be income from non-entrepreneurial activity and physical person has to pay income tax of $7100 \times 14$ per cent $=1008$ (one thousand eight) manat.

Income tax in individuals in Turkey is regulated by the "Income Tax Law" (Law No. 193), adopted on December 31, 1960, consisting of 126 articles. This Law, which has undergone a number of additions and changes so far, came into force on January 6, 1961 after its publication in the Official Gazette No. 10700 [3, p. 3].

Article 1 of the Income Tax Law of the Republic of Turkey states that the income of an individual means the income remaining after deducting the expenses incurred by an individual for income during a calendar year, including depreciation expenses and losses.

According to Article 2 of the above-mentioned Law, the following incomes of individuals shall be subject to taxation:
1) income from trade;

2) income received as a result of activities in the agricultural sector, ie income from the production and sale of plant and animal products;

3) salary - compensation paid by the employer to the employee in cash or in kind in relation to the work done in the workplace, ie products paid in kind instead of wages;

4) income received as a result of freely performing certain work;

5) income from real estate;

6) income from movable estate;

7) other gains $[1$, p. 3].

Part 2 of Article 2 of the Law of the Republic of Turkey «On Income Tax» states that, unless otherwise provided by this Law, the abovementioned income of individuals shall be subject to taxation.

According to the legislation, individuals who have been in Turkey for more than 6 (six) months in a calendar year shall be considered income taxpayers.

The rates of income tax levied on individuals are set out in Article 103 of the Income Tax Law as follows.

- If the amount of taxable annual income is up to 18,000 (eighteen thousand) Turkish lira - 15 percent;

- If the amount of taxable annual income is up to 40,000 (forty thousand) Turkish lira 2,700 (two thousand seven hundred) Turkish lira +20 percent of the amount exceeding + 18,000 (eighteen thousand) Turkish lira

- If the amount of taxable annual income is up to 98.000 (ninety eight thousand) Turkish lira +27 percent of the amount exceeding 40.000 (forty thousand) Turkish lira;

- If the amount of taxable annual income exceeding 98.000 (ninety-eight thousand) Turkish lira -22.760( twenty-two thousand seven hundred sixty) Turkish lira +35 per cent of the amount exceeding 98.000 (ninety -eight thousand) Turkish lira;

- If the amount of taxable annual income exceeding 148.000 (one hundred forty-eight thousand) Turkish lira - 36.260 (thirty six thousand and two hundreds sixty) Turkish lira +35 per cent of the amount exceeding 148.000 (one hundred forty-eight thousand) Turkish lira;

With the addition and amendment to Article 103 of the "Income Tax Law" of the Repub- 
lic of Turkey on December 5, 2019, the rates of income tax levied on individuals from January 1, 2020 were determined as follows:

$\S$ If the amount of taxable annual income is up to 22.000 (twenty two thousand) Turkish lira - 15 per cent;

$\S$ If the amount of taxable annual income is up to 49.000 (forty nine thousand) Turkish lira - 3.300 (three thousand three hundred) Turkish lira +20 per cent of the amout exceeding 22.000 (twenty two thousand) Turkish lira;

$\S$ If the amount of taxable annual income is up to 120.000 (one hundred twenty thousand) Turkish lira -8.700 (eight thousand seven hundred) Turkish lira +27 per cent of the amout exceeding 49.000 (forty thousand) Turkish lira;

$\S$ If the amount of taxable annual income is up to 180.000 (one hundred eighty thousand) Turkish lira - 8.700 (eight thousand seven hundred) Turkish lira +27 per cent of the amout exceeding 49.000 (forty thousand) Turkish lira;

$\S$ If the amount of taxable annual income is up to 600.000 (six hundred thousand) Turkish lira -27.870 (twenty seven thousand eight hundred seventy) Turkish lira +35 per sent of the amout exceeding 120.000 (one hundred twenty thousand) Turkish lira;

$\S$ If the amount of taxable annual income is up to 600.000 (six hundred thousand) Turkish lira -44.070 (forty four thousand seventy) Turkish lira +35 per sent of the amout exceeding 180.000 (one hundred eighty thousand) Turkish lira;

$\S$ If the amount of taxable annual income exceeds 600.000 (six hundred thousand) Turkish lira - 195.870 (one hundred ninety-five thousand, eight hundred seventy) Turkish lira +40 per cent of the amout exceeding 600.000 (six hundred thousand) Turkish lira;

$\S$ If the amount of taxable annual income exceeds 600.000 (six hundred thousand) Turkish lira - 191.070 (one hundred ninety-one thousand and seventy) Turkish lira +40 per cent of the amout exceeding 600.000 (six hundred thousand) Turkish lira.

We would like to inform you that currently 100 (one hundred) Turkish lira is about 28 (twenty eight) manats 58 (fifty eight) kopecks.

In Turkey, the annual tax is divided into 12 when calculating the monthly income tax, and 30 when calculating the daily tax.
Thus, in accordance with Article 31 of the "Income Tax Law" of the Republic of Turkey, the part of monthly income of first-degree disabled people in 2019 up to 1,200 (one thousand two hundred) Turkish lira, monthly income of second-degree disabled 650 (six hundred fifty) ) up to the Turkish lira, and the part of the monthly income of the third degree disabled people up to 290 (two hundred ninety) Turkish lira is exempt from income tax.

According to the relevant amendment to Article 31 of the "Income Tax Law" of the Republic of Turkey, the part of monthly income of disabled people of the first degree in 2020 up to 1,400 (thousand four hundred) Turkish lira, the monthly income of disabled people of second degree 790 (seven hundred ninety) to the Turkish lira, and the part of the monthly income of the third degree disabled people up to 350 (three hundred and fifty) Turkish lira is exempt from income tax.

Persons who have lost at least 80 (eighty) percent of their ability to work are disabled of the first degree, persons who have lost at least 60 (sixty) percent of their ability to work are disabled of the second degree, persons who have lost at least 40 (forty) percent of their ability to work are disabled of third-degree.

See the following examples:

Example 1. The annual income of a physical person working in Ankara in 2019 was 32,000 (thirty two thousand) Turkish lira. Income tax will be 5,500 (five thousand five hundred) Turkish lira.

Example 2. In 2019, a physical person living in the city of Rize rented an apartment for 22,000 (twenty two thousand) Turkish lira per year. Income tax will be 3,500 (three thousand five hundred) Turkish lira.

Example 3. The annual income of a physical person working in Istanbul in 2019 was 49,000 (forty-nine thousand) Turkish lira. Income tax will be 9,530 (nine thousand five hundred and thirty) Turkish lira.

Example 4. The annual income of a physical person working in Ankara in 2019 was 96,000 (ninety-six thousand) Turkish lira. Income tax will be 22,220 (twenty two thousand two hundred twenty) Turkish lira

Example 5. The annual income of a physical person working in Bursa in 2019 was 120,000 


\section{Банківське та фінансове право}

(one hundred and twenty thousand) Turkish lira. Income tax will be 28,700 (twenty-eight thousand seven hundred) Turkish lira.

Example 6. The annual income of a firstdegree disabled person working in Samsun in 2019 was 17,000 (seventeen thousand) Turkish lira. Since the part of the annual income of the first degree disabled people up to $1200 \times 12$ $=14.400$ (fourteen thousand four hundred) Turkish lira is exempt from income tax, the income tax will be calculated from the amount of $17000-14.400=2.600$ (two thousand six hundred) Turkish lira. That is, the income tax will be $2,600 \times 15$ percent $=390$ (three hundred and ninety) Turkish lira.

Example 7. The annual income of a seconddegree disabled person working in Kayseri in 2019 was 17,600 (seventeen thousand six hundred) Turkish lira. Since the part of the annual income of the disabled of the second degree up to $650 \times 12=7,800$ (seven thousand eight hundred) Turkish lira is exempt from income tax, the income tax will be calculated from the amount of $17,600-7,800=9,800$ (nine thousand eight hundred) Turkish lira. That is, the income tax will be $9,800 \times 15$ percent $=1,470$ (one thousand four hundred and seventy) Turkish lira.

Example 8. The annual income of a thirddegree disabled person working in Antalya in 2019 was 18,000 (eighteen thousand) Turkish lira. As the part of the annual income of the third degree disabled people up to $290 \times 12$ $=3.480$ (three thousand four hundred and eighty) Turkish lira is exempt from income tax, the income tax will be calculated from the amount of 18,000-3,480 = 14,520 (fourteen thousand five hundred twenty) Turkish lira. That is, the income tax will be $14,520 \times 15$ percent $=2,178$ (two thousand one hundred and seventy eight) Turkish lira.

Example 9. The income of a physical person working in Ankara in January 2020 was 1,800 (one thousand eight hundred) Turkish lira. Income tax will be 270 (two hundred and seventy) Turkish lira.

Example 10. The income of an individual working in Chanakkale in February 2020 was 1830 (one thousand eight hundred and thirty) Turkish lira. Income tax will be 274.5 (two hun- dred seventy four pounds fifty cents) (the lower unit of the Turkish lira is the penny).

Example 11. In March 2020, the income of a first-degree disabled person working in Bursa was 2,000 (two thousand) Turkish lira. Since the part of the monthly income of the first degree disabled people up to 1,400 Turkish lira is exempt from income tax, the income tax will be calculated from the amount of 2,000-1,400 = 600 (six hundred) Turkish lira. That is, the income tax will be $600 \times 15$ percent $=90$ (ninety) Turkish lira.

The Revenue General Directorate of the Ministry of Treasury and Finance of Turkey controls the correct collection and timely payment of taxes in Turkey.

Thus, the research allows us to draw the following conclusions.

1) The rules of withholding income tax from individuals in the Republic of Azerbaijan are regulated by the Tax Code, but the Tax Code has not been adopted in Turkey. In this country, issues related to the collection of income tax from individuals are regulated by the "Income Tax Law".

2) The upper limit of the tax levied on individuals in Turkey is higher than in the Republic of Azerbaijan. Thus, while the upper limit of personal income tax in our country is 25 percent, the upper limit of the tax in Turkey is 40 percent.

3) Compared to the Republic of Azerbaijan, Turkish legislation provides for more tax benefits for people with disabilities. In our opinion, taking advantage of the positive aspects of the Turkish tax legislation, it would be expedient to amend Articles 102.2 and 102.3 of the Tax Code of the Republic of Azerbaijan in order to reduce the income tax levied on persons with disabilities of groups I and II.

- 102.2. The monthly income of the following individuals, which is subject to taxation from any employment, is reduced by 800 (eight hundred) manats;

- 102.3. Monthly income of persons with disabilities of groups I and II (except for war disabled veterans), persons with disabilities under 18 years of age, which are subject to taxation from any paid work, shall be reduced by 600 (six hundred) manats 
BIBLIOGRAPHIC REFERENGES

1. Alaattin Demir. Gelir Üzerinden Alınan Vergiler. İstanbul: On İki Levha Yayıncılık A.S., 2019, $543 \mathrm{~s}$.

2. Cəfərli N.H. Müqayisəli hüquqşünaslıq: Dərs vəsaiti. Bakı: Elm və təhsil, 2018, 332 s.

3. Gelir Vergisi Kanunu (Kanun Numarası: 193). Tüm Vergi Kanunları. İstanbul: Huz Akademi Yayıncılık A.Ş., 2019, $1274 \mathrm{~s}$.

4. Quliyev A.İ. Müqayisəli hüquqşünaslıq. Bakı: «Afpoliqraf» mətbəəsi, 2019, 240 s.

5. Ансель М. Методологические проблемы сравнительного права // Очерки сравнительного права / Отв. ред. В.А.Туманов. М.: Прогресс, 1981 , с. $36-86$

6. Налоговый кодекс Азербайджанской Республики от 11 июля 2000 года. https:// online.zakon.kz/document/?doc_id=30414629
Гасымзаде Рамиз Айдън оглу, кандидат юридических наук Докторант Начиональной Академии Авиачии Азербайджана ПОДОХОДНЫЙ НАЛОГ С ФИЗИЧЕСКИХ АИЦ: СРАВНИТЕЛЬНЫЙ АНАЛИЗ ЗАКОНОДАТЕАЬСТВА АЗЕРБАЙДЖАНСКОЙ РЕСПУБАИКИ И ТУРЦИИ

В статье указывается, что сравнительное правоведение выступает как важная форма развития международных связей. Сравнительное правоведение несёт высокий заряд правовой культуры, активно способствует выработке юридического мышления, дает необходимые юристу знания.

Ключевые слова: Азербайджан, право, сравнительный, страна, налог. 